І. В. Лінський, В. Н. Кузъмінов, О. І. Мінко, Г. М. Кожина, Є. Г. Гриневич, М. О. Овчаренко, В. В. Чугунов,

В. М. Пострелко, М. М. Денисенко, В. А. Плєхов, Т. В. Ткаченко, В. В. Задорожний, Н. А. Малихіна, О. О. Мінко, Р. В. Лакинський, О. О. Васильєва, О. М. Юриенко, Б. О. Герасимов, Д. О. Герасимов ВПЛИВ ПИТУЩИХ НА АФЕКТИВНИЙ СТАТУС ПРЕДСТАВНИКІВ ÏХНЬОГО МІКРОСОЦІАЛЬНОГО ОТОЧЕННЯ

И. В. Линский, В. Н. Кузвминов, А. И. Минко, А. М. Кожина, Е. Г. Гриневич, Н. А. Овчаренко, В. В. Чугунов,

В. М. Пострелко, М. М. Денисенко, В. А. Плехов, Т. В. Ткаченко, В. В. Задорожный, Н. А. Мальхина, А. А. Минко, Р. В. Лакинский, О. А. Васильева, О. Н. Юрченко, Б. А. Герасимов, Д. А. Герасимов Влияние пьющих на аффективный статус представителей их микросоциального окружения

\author{
I. V. Linskiy, V. N. Kuzminov, O. I. Minko, H. M. Kozhyna, Ye. G. Grynevych, M. O. Ovcharenko, V. V. Chugunov, \\ V. M. Postrelko, M. M. Denysenko, V. A. Plekhov, T. V. Tkachenko, V. V. Zadorozhnyi, N. A. Malykhina, \\ O. O. Minko, R. V. Lakinskyi, O. O. Vasilyeva, O. M. Yurchenko, B. O. Herasymov, D. O. Herasymov
}

\title{
The influence of drinkers on the affective status of representatives of their microsocial environment
}

Мета роботи - вивчення несприятливого впливу питущих осіб на афективний статус представників їхнього мікросоціального оточення.

В чотирьох регіонах України (Харківська, Луганська та Запорізька області, а також місто Київ) протягом 20182021 років обстежено 1742 особи, які належали до трьох якісно відмінних груп порівняння: хворі на алкогольну залежність (АЗ) (393 особи); здорові родичі хворих на АЗ (274 особи) і представники загальної популяції (1075 осіб). Із цих обстежених були виокремлені респонденти, що мали питущих в своєму оточенні: 288 осіб серед здорових і 121 особу серед хворих на АЗ. Подальші дослідження були зосереджені саме на цьому контингенті. Основним інструментом дослідження був опитувальник міжнародного дослідницького консорціуму GENAHTO (Gender, Alcohol, and Harms to Others) та шкала для оцінки депресії Hamilton (HDRS). Отримані дані обробляли методами математичної статистики (дисперсійний та кластерний аналізи) на комп'ютері за допомогою обчислювальних таблиць Excel 2016 (з пакетом «Аналіз даних»), а також програмного пакету SPSS-15.

Показано, що наявність питущих в оточенні жінок істотно підвищує серед них відносну частку осіб з депресивними розладами, тоді як у респондентів чоловічої статі такого ефекту виявлено не було. Встановлено, що в разі наявності питущих в оточенні у жінок найбільше зростає виразність таких проявів депресії: безсоння; зменшення маси тіла, розлади сексуальної сфери; суїцидальні тенденції і почуття провини. За допомогою кластерного аналізу встановлені важливі для обрання оптимальної терапевтичної тактики типові симптомокомплекси: інсомнічно-соматоформний, іпохондричний та анксіозно-ажитаційний (останній - з відчуттям власної провини і підвищеним ризиком суїцидальної активності).

Ключові слова: споживання алкоголю, шкода для інших, афективний статус, гендерні особливості
Цель работы - изучение неблагоприятного влияния пьющих на аффективный статус представителей их микросоциального окружения.

В четырех регионах Украины (Харьковская, Луганская и Запорожская области, а также город Киев) в течение 2018-2021 годов обследовано 1742 человека, которые принадлежали к трем качественно различным группам сравнения: больные алкогольной зависимостью (АЗ) (393 человека); здоровые родственники больных АЗ (274 человека) и представители общей популяции (1075 человек). Из этих обследованных были выделены респонденты, имевшие пьющих в своем окружении: 288 человек среди здоровых і 121 человек среди больных А3. Дальнейшие исследования были сосредоточены именно на этом контингенте. Основным инструментом исследования был опросник международного исследовательского консорциума GENAHTO (Gender, Alcohol, and Harms to Others) и шкала для оценки депрессии Hamilton (HDRS). Полученные данные обрабатывали методами математической статистики (дисперсионный и кластерный анализы) на компьютере с помощью вычислительных таблиц Excel 2016 (с пакетом «Анализ данных», а также программного пакета SPSS-15.

Показано, что наличие пьющих в окружении женщин значительно повышает среди них относительную долю лиц с депрессивными расстройствами, в то время как у респондентов мужского пола такого эффекта выявлено не было. Установлено, что при наличии пьющих в окружении у женщин в большей степени возрастает выраженность таких проявлений депрессии: бессонница; потеря веса, расстройства сексуальной сферы; суицидальные тенденции и чувство вины. С помощью кластерного анализа установлены важные для выбора оптимальной терапевтической тактики типичные симптомокомплексы: инсомнично-соматоформный, ипохондрический и анксиозно-ажитационный (последний - с чувством вины и повышенным риском суицидальной активности).

Ключевые слова: потребление алкоголя, вред для других, аффективный статус, гендерные особенности
The purpose of the work is to study the adverse influence of drinkers on the affective status of representatives of their microsocial environment.

In four regions of Ukraine (Kharkiv, Lugansk and Zaporizhzhia regions, as well as the city of Kyiv), during 2018-2021, 1742 people were examined, who belonged to three qualitatively different comparison groups: patients with alcohol dependence (AD) (393 people); healthy relatives of alcohol-dependent patients (274 people) and representatives of the general population (1075 people). Of these surveyed, respondents were identified who had drinkers in the environment: 288 persons among healthy people and 121 persons among patients with $A D$. Further research focused on this particular contingent. The main research tool was the questionnaire of the international research consortium GENAHTO (Gender, Alcohol, and Harms to Others) and Hamilton Depression Rating Scale (HDRS). The obtained data were processed by methods of mathematical statistics (variance and cluster analysis) on a computer using Excel 2016 computational tables (with the Data Analysis package) and also the software package SPSS- 15.

It was shown that the presence of drinkers in environment of the women significantly increases the proportion of people with depressive disorders among them, while among the male respondents, this effect was not found. It was revealed that the presence of drinkers in environment of the women significantly increases the severity of such manifestations of depression as: insomnia, weight loss, sexual dysfunctions; suicidal tendencies and guilt. Using cluster analysis, the following typical symptom complexes (important for choosing the optimal therapeutic tactics) were established: insomnia-somatoform, hypochondriacal and anxiety-agitational (the latter - with a sense of guilt and an increased risk of suicidal activity).

Keywords: alcohol consumption, harm to others, affective status, gender peculiarities

Першу, другу та третю частини дослідження опубліковано: Український вісник психоневрології. 2021. Т. 29, вип. 1 (106), вип. 2 (107), вип. 3 (108). () Лінський І. В., Кузьмінов В. Н., Мінко О. І,, Кожина Г. М., Гриневич Є. Г., Овчаренко М. О., Чугунов В. В., Пострелко В. М., Денисенко М. М., Плєхов В. А., Ткаченко Т. В., Задорожний В. В., Малихіна Н. А., Мінко О. О., Лакинський Р. В., Васильєва О. О., Юрченко О. М., Герасимов Б. О., Герасимов Д. О., 2021 
Відомо, що вживання алкоголю супроводжу$\epsilon$ ться численними несприятливими наслідками не тільки для самих його споживачів, а й для інших людей [1-3]. Спектр цієї «шкоди для інших» (ШДІ) $\epsilon$ вельми широким: від дорожньо-транспортних пригод, спричинених п'яними водіями [4-6], до насильства у родинах $[7,8]$. Водночас особливої уваги варті несприятливі наслідки алкоголізації для психічного здоров'я людей в близькому оточенні питущих ${ }^{*}$ [9-11]. Загалом збитки суспільства внаслідок ШДІ можуть бути вдвічі більшими, ніж збитки внаслідок шкоди для самих питущих [12]. Ось чому ВОО3 розглядає заходи протидії ШДІ як невід'ємний складник ефективної алкогольної політики [13].

Всесвітній масштаб проблеми ШДІ потребує для її розв'язання широкої дослідницької кооперації, яка отримала своє втілення, зокрема, в міжнародному консорціумі для реалізації проєкту GENAHTO (Gender, Alcohol, and Harms to Others - Ґендер, Алкоголь та Шкода для Інших) [14], до участі в якому 2018 року долучилась і Україна.

Ця стаття $\epsilon$ четвертою в серії публікацій, присвячених результатам реалізації української частини проєкту GENAHTO. Першу статтю $з$ цієї серії було присвячено оцінюванню масштабів ШДІ в українському суспільстві, її ґендерним та віковим особливостям [15], другу і третю - проявам несприятливого впливу питущих на дорослих [16] і дітей [17] в мікросоціальному оточенні згаданих питущих.

Метою цієї роботи стало вивчення несприятливого впливу питущих осіб на афективний статус представників їхнього мікросоціального оточення.

Для реалізації українського фрагмента міжнародного проєкту GENAHTO було створено власний консорціум дослідників, який об'єднав фахівців чотирьох регіонів нашої держави, а саме: Харківської, Луганської та Запорізької областей, а також міста Києва. Обстеження респондентів в згаданих регіонах тривало протягом 2018-2021 років.

Загалом було обстежено 1742 особи, які належали до трьох груп порівняння, що якісно відрізняються. I групу становили хворі на алкогольну залежність (АЗ) (393 особи, серед них - 359 чоловіків і 34 жінки); II групу - здорові родичі хворих на А3 (274 особи, серед них - 98 чоловіків і 176 жінок) і III групу (контрольну) - представники загальної популяції (1075 осіб, зокрема - 347 чоловіків і 728 жінок). Із 1075 членів контрольної групи більшу частину становили студенти 3-4 курсів медичних вишів (741 особа, серед них 227 чоловіків і 514 жінок), і ще 334 особи (серед них 120 чоловіків і 214 жінок) були відібрані із загальної популяції випадково. Про переваги і недоліки такого способу формування досліджуваного контингенту докладно йшлося у попередніх публікаціях [15-16].

Основним інструментом дослідження був опитувальник консорціуму GENAHTO [17], який має

* Тут і далі в цій статті термін «питущі» охоплює людей, які мають ознаки згубного вживання алкоголю (код F10.1 за MKX-10) або синдрому залежності від цієї психоактивної речовини (код F10.2 за MKX-10). дві частини, перша із яких присвячена самому респонденту, а друга - оточенню респондента. Перша частина опитувальника складається із п'яти розділів: $a$ - соціально-демографічна характеристика респондента; $b-$ характеристика алкоголізації респондента; с - стан здоров'я і стиль життя респондента; $d$ - добробут і якість життя респондента та е - шкода для респондента від пияцтва оточення. Друга частина опитувальника складається з семи розділів: $f$ - близькі питущі у житті респондента; $g$ - турбота респондента про близьких питущих; $h$ - сімейно-демографічна характеристика близьких питущих; $i$ - діти респондента; $j$ - питущі співробітники респондента; $k$ - питущі незнайомці респондента та I - пошук допомоги близьким питущим респондента.

Окрім опитувальника консорціуму GENAHTO, в дослідженні використовували шкалу для оцінки депресії Hamilton (HDRS) [18]. За допомогою цієї шкали вдалося обстежити лише 1475 осіб, саме тому описані нижче дослідження стосуються саме цього контингенту. Обстеження виконували треновані інтерв'юери методом "face to face" зазвичай протягом 1,5-2 годин, однократно, після отримання відповідної інформованої згоди від респондентів.

3 огляду на те, що ця стаття $\epsilon$ однією із серії подібних публікацій, в ній буде висвітлено лише частину інформації, отриманої за допомогою згаданого вище інструментарію.

Отримані дані обробляли методами математичної статистики (дисперсійний та кластерний аналіз [19, 20]) на комп'ютері за допомогою обчислювальних таблиць Excel 2016 (з пакетом «Аналіз даних»), а також програмного пакету SPSS-15.

Викладення результати дослідження, про яке йдеться, доцільно розпочати з аналізу розподілів респондентів різних груп порівняння за рівнем депресії (табл. 1 і 2, рис. 1), з урахуванням фактору наявності/відсутності питущих в оточенні (ПВО).

Як можна бачити, розподіл хворих на АЗ радикально відрізняється від такого розподілу у практично здорових респондентів (рис. 1). Якщо серед здорових цілком очікувано домінують особи без ознак депресивних розладів (ДР), то у хворих на АЗ таких осіб не більше ніж $10 \%$, тоді як у решти спостерігаються ДР різного ступеня важкості.

Також добре помітно, що у практично здорових респондентів наявність ПВО істотно підвищує відносну частку осіб з ДР всіх ступенів важкості (див. табл. 1): легкого - на 31,03 \%, середнього на 21,52 \%, тяжкого і вкрай тяжкого - на 199,49\% $(p<0,01)$.

Ще більшої виразності цей феномен набуває, як порівняти практично здорових респондентів без ПВО з родичами хворих на АЗ (див. табл. 1). В цьому випадку відносна частка осіб з ДР достовірно $(p<0,01)$ підвищується на 84,49\%, 124,80\% і 283,84 \% (для легкого, середнього, а також тяжкого і вкрай тяжкого ступенів важкості цих розладів відповідно). Коментуючи це спостереження, варто 
наголосити, що в оточенні родичів хворих на АЗ $\epsilon$ не просто питущі, а особи з верифікованою залежністю від алкоголю, негативний вплив яких на їхніх близьких є суттєво більш інтенсивним. Отже, той факт, що підсилення згаданого негативного впливу (при переході від групи практично здорових осіб з ПВО до групи родичів хворих на АЗ) супроводжу- ється збільшенням відносної частки осіб з ДР різного ступеня важкості дає змогу стверджувати, що саме наявність ПВО є причиною ДР, про які йдеться, бо залежність ефекту від сили впливу (з посиленням впливу ефект збільшується і навпаки) $є$ одним із найважливіших свідчень наявності причинно-наслідкового зв'язку за А. B. Hill [21].

Таблиця 1. Розподіли хворих на алкогольну залежність і здорових респондентів за рівнем депресії (за шкалою HDRS) залежно від наявності/відсутності питущих в оточенні

\begin{tabular}{|c|c|c|c|c|c|c|c|c|c|c|}
\hline \multirow{4}{*}{ Ознаки } & \multicolumn{10}{|c|}{ Частоти ознак, \% } \\
\hline & \multicolumn{3}{|c|}{ Здорові, $n=1146$} & \multicolumn{2}{|c|}{$p$} & \multicolumn{2}{|c|}{$\begin{array}{c}\text { Хворі на A3 («X»), } \\
n=329\end{array}$} & \multicolumn{3}{|c|}{$p$} \\
\hline & \multicolumn{2}{|c|}{ Контроль («К»), $n=909$} & \multirow{2}{*}{ 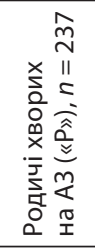 } & \multirow{2}{*}{ 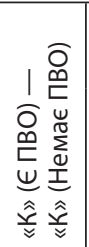 } & \multirow[b]{2}{*}{ 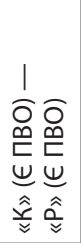 } & \multirow[b]{2}{*}{ 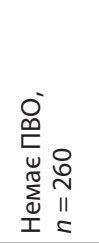 } & \multirow[b]{2}{*}{ 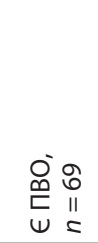 } & \multirow{2}{*}{ 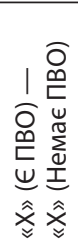 } & \multirow[b]{2}{*}{ 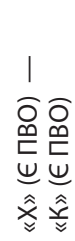 } & \multirow{2}{*}{ 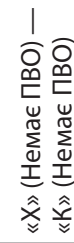 } \\
\hline & 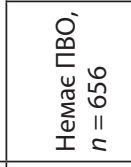 & 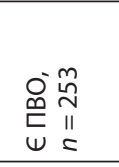 & & & & & & & & \\
\hline Норма (0-7 балів) & 78,96 & 69,57 & 55,27 & \multirow{5}{*}{$\begin{array}{l}\stackrel{n}{\kappa} \\
\hat{n} \\
\varnothing \\
0\end{array}$} & \multirow{5}{*}{$\frac{\tilde{m}}{\frac{n}{\sigma}}$} & 8,08 & 8,70 & \multirow{5}{*}{$\begin{array}{l}\bar{\sigma} \\
\infty \\
\frac{0}{0}\end{array}$} & \multirow{5}{*}{$\begin{array}{l}\overline{8} \\
8 \\
8 \\
0 \\
\text { v }\end{array}$} & \multirow{5}{*}{$\begin{array}{l}\overline{8} \\
8 \\
8 \\
0 \\
0 \\
v\end{array}$} \\
\hline Легкий ДР (8-13 балів) & 14,18 & 18,58 & 26,16 & & & 26,54 & 27,54 & & & \\
\hline Середньої тяжкості ДР (14-18 балів) & 4,88 & 5,93 & 10,97 & & & 27,69 & 15,94 & & & \\
\hline Тяжкий ДР (19-22 балів) & 1,07 & 1,98 & 4,22 & & & 21,15 & 18,84 & & & \\
\hline Вкрай тяжкий ДР ( $\geq 23$ балів) & 0,91 & 3,95 & 3,38 & & & 16,54 & 28,99 & & & \\
\hline
\end{tabular}

Примітки. Тут і далі: «Є ПВО» — наявність, «Немає ПВО» — відсутність питущої особи в оточенні респондента (для хворих окрім самого респондента); $p$ - відмінності між розподілами різних груп порівняння за критерієм $x^{2}$. Достовірні відмінності $(p<0,05)$ виділені заливкою сірого кольору
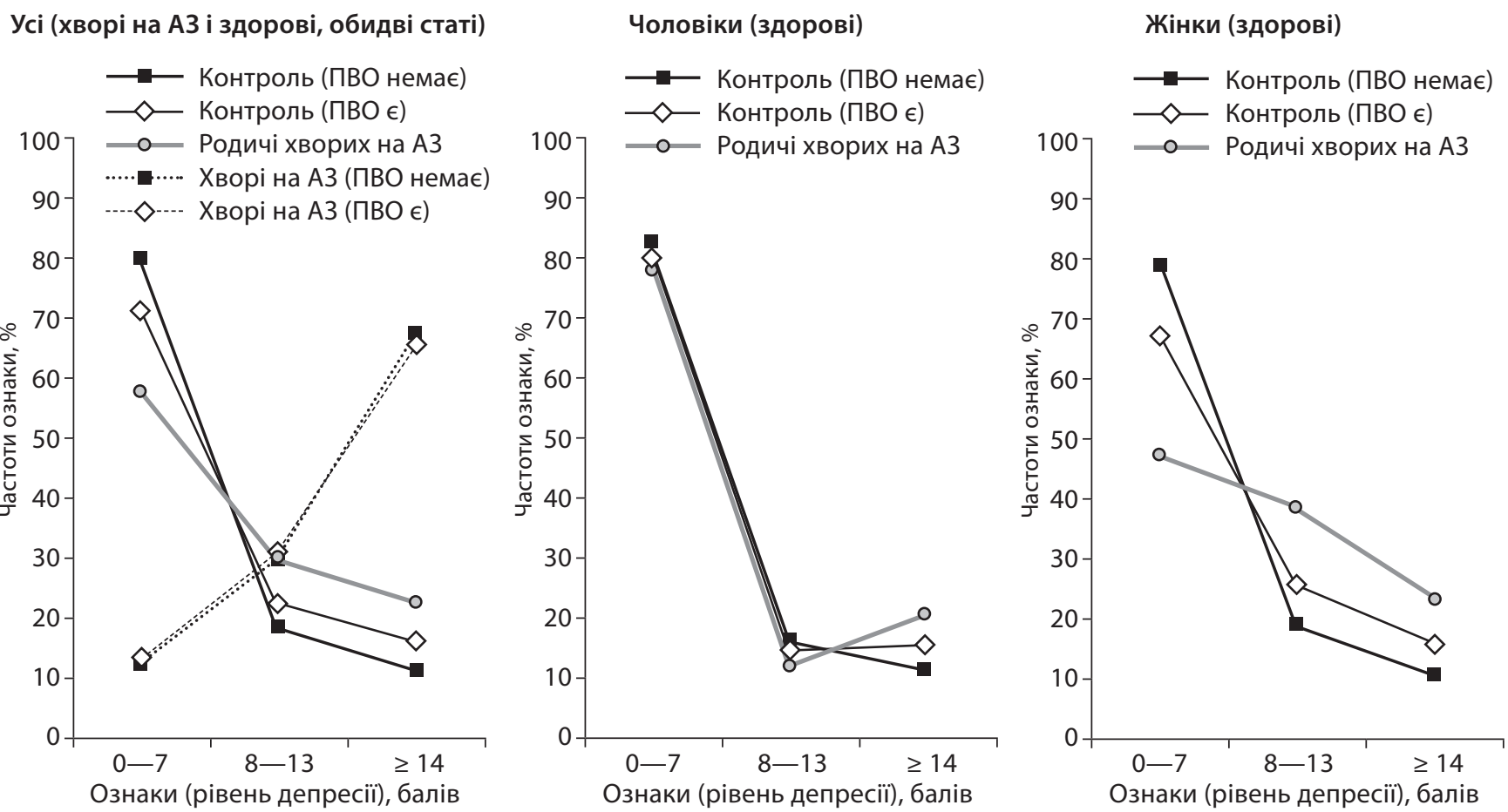

PUc. 1. Розподіли обстежених респондентів за рівнем депресії (за шкалою HDRS) залежно від наявності/відсутності Пво Скорочення: Контроль (ПВО немає) — представники групи контролю (здорові особи) без ПВО в оточенні.

Контроль (ПВО $\epsilon$ ) — представники групи контролю (здорові особи) з ПВО в оточенні.

Родичі хворих на АЗ - представники групи родичів хворих на АЗ (здорові особи, що мають ПВО в оточенні, а саме - хворих на АЗ).

Хворі на АЗ (ПВО немає) - представники групи хворих на АЗ без ПВО (окрім самого респондента) в оточенні.

Хворі на АЗ (ПВО $\epsilon)$ - представники групи хворих на АЗ з ПВО (окрім самого респондента) в оточенні 
Таблиця 2. Розподіли здорових респондентів різної статі за рівнем депресії (за шкалою HDRS) залежно від наявності/відсутності питущих в оточенні

\begin{tabular}{|c|c|c|c|c|c|c|c|c|c|c|c|c|}
\hline \multirow{4}{*}{ Ознаки } & \multicolumn{12}{|c|}{ Частоти ознак, \% } \\
\hline & \multicolumn{3}{|c|}{ Чоловіки, $n=372$} & \multicolumn{2}{|c|}{$p$} & \multicolumn{3}{|c|}{ Жінки, $n=774$} & \multicolumn{4}{|c|}{$p$} \\
\hline & \multicolumn{2}{|c|}{$\begin{array}{c}\text { Контроль («К»), } \\
n=292\end{array}$} & \multirow{2}{*}{ 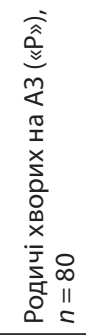 } & \multirow[b]{2}{*}{ 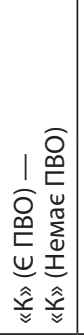 } & \multirow[b]{2}{*}{ 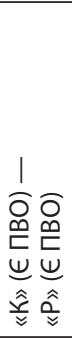 } & \multicolumn{2}{|c|}{ Контроль, $n=617$} & \multirow{2}{*}{ 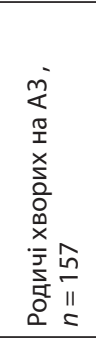 } & \multirow[b]{2}{*}{ 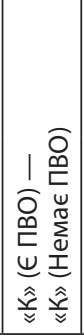 } & \multirow{2}{*}{ 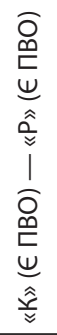 } & \multirow{2}{*}{ 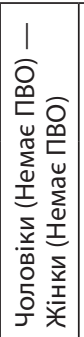 } & \multirow{2}{*}{ 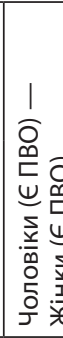 } \\
\hline & 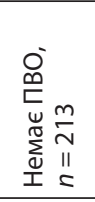 & 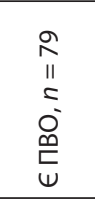 & & & & 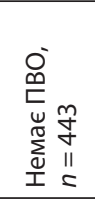 & 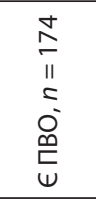 & & & & & \\
\hline Норма (0-7 балів) & 81,22 & 78,48 & 76,25 & \multirow{5}{*}{$\frac{\hat{m}}{\frac{\infty}{\sigma}}$} & \multirow{5}{*}{$\begin{array}{l}\infty \\
\delta \\
\check{\delta} \\
\end{array}$} & 77,88 & 65,52 & 44,59 & \multirow{5}{*}{$\begin{array}{l}\bar{n} \\
\stackrel{m}{0} \\
0\end{array}$} & \multirow{5}{*}{$\begin{array}{l}\text { N } \\
\text { ñ } \\
\text { ○े } \\
0 \\
0\end{array}$} & \multirow{5}{*}{$\begin{array}{l}\stackrel{+}{~} \\
\stackrel{n}{0} \\
\infty \\
0\end{array}$} & \\
\hline Легкий ДР (8-13 балів) & 11,74 & 10,13 & 7,50 & & & 15,35 & 22,41 & 35,67 & & & & \\
\hline Середньої тяжкості ДР (14-18 балів) & 5,16 & 3,80 & 12,50 & & & 4,74 & 6,90 & 10,19 & & & & \\
\hline Тяжкий ДР (19-22 бали) & 0,94 & 2,53 & 2,50 & & & 1,13 & 1,72 & 5,10 & & & & \\
\hline Вкрай тяжкий ДР ( 223 бали) & 0,94 & 5,06 & 1,25 & & & 0,90 & 3,45 & 4,46 & & & & \\
\hline
\end{tabular}

До сказаного слід додати, що описані вище феномени мають виразні ґендерні особливості (див. рис. 1, табл. 2). Вони полягають в тому, що наявність ПВО впливає, насамперед, на жінок. Зокрема, саме у практично здорових жінок наявність ПВО істотно підвищує відносну частку осіб з ДР всіх ступенів важкості (див. табл. 2): легкого - на 45,99 \%, середнього на 45,57 \%, тяжкого і вкрай тяжкого - на $154,68 \%$ $(p<0,05)$. Ця різниця стає ще більш значущою, як порівняти практично здорових жінок без ПВО 3 жінками - родичами хворих на АЗ (див. табл. 2). В цьому випадку відносна частка осіб з ДР достовірно підвищується на 132,38 \%, 114,98 \% і $370,94 \%$ (для легкого, середнього, а також тяжкого і вкрай тяжкого ступенів важкості цих розладів відповідно, при $p<0,01)$. Водночас, у чоловіків наявність ПВО практично не впливала на відносну частку осіб з ДР будь-яких ступенів важкості (див. рис. 1, табл. 2).

Наступний етап роботи був присвячений аналізу ступеня виразності ДР загалом та окремих їхніх проявів у групах порівняння (табл. 3, 4, рис. 2, 3).

Отримані дані (див. табл. 3, рис. 2) свідчать про те, що у здорових респондентів наявність ПВО достовірно $(p<0,001)$ підвищує середній рівень виразності ДР загалом (сума балів за шкалою HDRS) в 1,38 раза, коли йдеться про будь-яких ПВО, і в 1,85 раза, коли ПВО $є$ особою з АЗ.

Однак виразність окремих проявів ДР (симптомів) збільшується не рівною мірою (див. табл. 3, рис. 2). Зокрема, найбільше зростання (порівняно із здоровими респондентами без ПВО) демонструють середнє і пізнє безсоння; розлади сексуальної сфери; порушення з боку шлунково-кишкового тракту (ШКТ); зменшення маси тіла та почуття провини (в 4,15; в 2,95; в 2,50; в 2,44; в 2,44 і 2,30 раза у родичів хворих на A3 та в 2,00 ; в 1,45 ; в 1,80 ; в 1,78 ; в 2,00 і в 1,48 раза у здорових респондентів з ПВО відповідно при $p \leq 0,01$ ).

На відміну від цього, у хворих на АЗ наявність ПВО впливає на їхній і без того уражений психічний статус істотно менш інтенсивно. Досить сказати, що середній рівень виразності ДР загалом (сума балів за шкалою HDRS) у хворих на АЗ з ПВО лише в 1,15 раза більше, ніж у хворих на АЗ без ПВО $(p=0,025)$. Також відрізняється перелік окремих проявів ДР, виразність яких зазнає найбільшого зростання в разі появи ПВО у хворих на АЗ. Це, насамперед: ажитація; зниження працездатності і активності; порушення з боку ШКТ; психічна і соматична тривога та знижений настрій (в 1,66 ; в 1,64 ; в 1,33 ; в 1,27 ; в 1,23 і в 1,26 раза відповідно, при $p<0,02$ ).

Як і вже згадані розподіли респондентів за рівнем депресії, ступені виразності ДР загалом та окремих їхніх проявів в групах порівняння мають істотні ґендерні особливості (див. табл. 4, рис. 3). Наприклад, у здорових чоловіків наявність ПВО практично не впливала на рівень виразності ДР загалом. Різниця між сумами балів за шкалою HDRS у відповідних групах не була достовірною (див. табл. 4). Водночас спостерігалось достовірне збільшення виразності поодиноких симптомів ДР, а саме: порушень 3 боку ШКТ (в 2,11 раза при $p=0,037)$ в групі здорових чоловіків з будь-якими ПВО, а також середнього і пізнього безсоння в групі здорових чоловіків - родичів хворих на АЗ (в 3,00 і в 2,38 раза відповідно, при $p<0,02$ ).

Водночас, у здорових жінок наявність ПВО достовірно $(p<0,001)$ підвищує середній рівень виразності ДР загалом (сума балів за шкалою HDRS) в 1,45 раза, коли йдеться про будь-яких ПВО, і в 2,01 раза, коли ПВО $\epsilon$ особою з АЗ (див. табл. 4, рис. 3). До того ж найбільше зростання (порівняно із здоровими жінками без ПВО) спостерігалось за показниками: середнє і пізнє безсоння; зменшення маси тіла, розлади сексуальної сфери; суїцидальні тенденції та почуття провини (в 4,57; в 3,17; в 3,50; в 3, 13; в 2,90 і 2,54 раза у жінок - родичів хворих на АЗ та в 2,29; в 1,48; в 1,$88 ;$ в 2,38; в 2,10 і в 1,46 раза у жінок з будь-якими ПВО відповідно, при $p \leq 0,04)$. 
Таблиця 3. Середні значення показників за шкалою HDRS у хворих на алкогольну залежність і здорових респондентів залежно від наявності/відсутності питущих в оточенні

\begin{tabular}{|c|c|c|c|c|c|c|c|c|c|c|}
\hline & \multicolumn{3}{|c|}{ Здорові, $n=1202$} & \multicolumn{2}{|c|}{$p$} & \multicolumn{2}{|c|}{ Хворі на АЗ $(« Х »), n=329$} & \multicolumn{3}{|c|}{$p$} \\
\hline & \multicolumn{2}{|c|}{$\begin{array}{c}\text { Контроль («К»), } \\
n=964\end{array}$} & \multirow{2}{*}{ 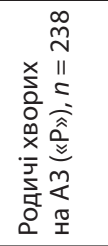 } & \multirow{2}{*}{ 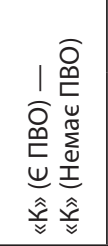 } & \multirow{2}{*}{ 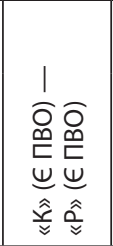 } & \multirow[b]{2}{*}{ 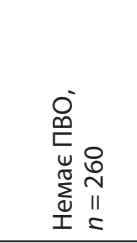 } & \multirow[b]{2}{*}{ 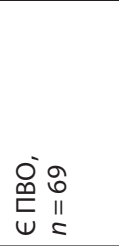 } & \multirow{2}{*}{ 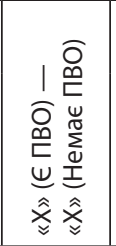 } & \multirow{2}{*}{ 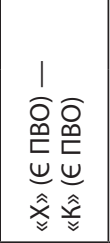 } & \multirow{2}{*}{ 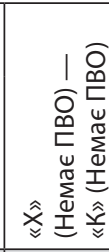 } \\
\hline & 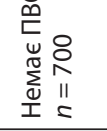 & 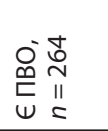 & & & & & & & & \\
\hline 1. Знижений настрій & $\begin{array}{l}0,49 \\
\pm 0,04\end{array}$ & $\begin{array}{c}0,68 \\
\pm 0,06\end{array}$ & $\begin{array}{l}0,80 \\
\pm 0,06\end{array}$ & 0,004 & 0,081 & $\begin{array}{l}1,52 \\
\pm 0,07\end{array}$ & $\begin{array}{l}1,91 \\
\pm 0,14\end{array}$ & 0,007 & $<0,001$ & $<0,001$ \\
\hline 2. Почуття провини & $\begin{array}{c}0,23 \\
\pm 0,02\end{array}$ & $\begin{array}{c}0,34 \\
\pm 0,04\end{array}$ & $\begin{array}{l}0,53 \\
\pm 0,05\end{array}$ & 0,009 & 0,003 & $\begin{array}{l}1,58 \\
\pm 0,06\end{array}$ & $\begin{array}{l}1,55 \\
\pm 0,14\end{array}$ & 0,432 & $<0,001$ & $<0,001$ \\
\hline 3. Суїцидальні тенденції & $\begin{array}{l}0,12 \\
\pm 0,02\end{array}$ & $\begin{array}{l}0,19 \\
\pm 0,04\end{array}$ & $\begin{array}{l}0,22 \\
\pm 0,04\end{array}$ & 0,053 & 0,315 & $\begin{array}{l}0,80 \\
\pm 0,07\end{array}$ & $\begin{array}{c}0,88 \\
\pm 0,12\end{array}$ & 0,273 & $<0,001$ & $<0,001$ \\
\hline $\begin{array}{l}\text { 4. Раннє безсоння (труднощі } \\
\text { при засинанні) }\end{array}$ & $\begin{array}{l}0,29 \\
\pm 0,02\end{array}$ & $\begin{array}{c}0,38 \\
\pm 0,04\end{array}$ & $\begin{array}{l}0,55 \\
\pm 0,04\end{array}$ & 0,031 & 0,001 & $\begin{array}{c}1,21 \\
\pm 0,04\end{array}$ & $\begin{array}{l}1,06 \\
\pm 0,08\end{array}$ & 0,059 & $<0,001$ & $<0,001$ \\
\hline 5. Середнє безсоння & $\begin{array}{l}0,13 \\
\pm 0,02 \\
\end{array}$ & $\begin{array}{l}0,26 \\
\pm 0,03 \\
\end{array}$ & $\begin{array}{l}0,54 \\
\pm 0,04 \\
\end{array}$ & $<0,001$ & $<0,001$ & $\begin{array}{l}1,13 \\
\pm 0,05 \\
\end{array}$ & $\begin{array}{l}1,10 \\
\pm 0,10 \\
\end{array}$ & 0,412 & $<0,001$ & $<0,001$ \\
\hline $\begin{array}{l}\text { 6. Пізнє безсоння (ранні про- } \\
\text { будження) }\end{array}$ & $\begin{array}{l}0,22 \\
\pm 0,02\end{array}$ & $\begin{array}{l}0,32 \\
\pm 0,04\end{array}$ & $\begin{array}{l}0,65 \\
\pm 0,05\end{array}$ & 0,010 & $<0,001$ & $\begin{array}{l}1,05 \\
\pm 0,05\end{array}$ & $\begin{array}{l}1,13 \\
\pm 0,09\end{array}$ & 0,237 & $<0,001$ & $<0,001$ \\
\hline $\begin{array}{l}\text { 7. Працездатність } \\
\text { та активність }\end{array}$ & $\begin{array}{l}0,35 \\
\pm 0,03 \\
\end{array}$ & $\begin{array}{l}0,49 \\
\pm 0,05 \\
\end{array}$ & $\begin{array}{l}0,63 \\
\pm 0,04 \\
\end{array}$ & 0,005 & 0,019 & $\begin{array}{c}0,97 \\
\pm 0,06 \\
\end{array}$ & $\begin{array}{l}1,59 \\
\pm 0,17 \\
\end{array}$ & $<0,001$ & $<0,001$ & $<0,001$ \\
\hline 8. Загальмованість & $\begin{array}{l}0,12 \\
\pm 0,02\end{array}$ & $\begin{array}{c}0,17 \\
\pm 0,03\end{array}$ & $\begin{array}{l}0,16 \\
\pm 0,03\end{array}$ & 0,071 & 0,325 & $\begin{array}{c}0,56 \\
\pm 0,04\end{array}$ & $\begin{array}{l}0,72 \\
\pm 0,11\end{array}$ & 0,089 & $<0,001$ & $<0,001$ \\
\hline 9. Ажитація (збудження) & $\begin{array}{c}0,24 \\
\pm 0,02 \\
\end{array}$ & $\begin{array}{l}0,36 \\
\pm 0,05\end{array}$ & $\begin{array}{c}0,24 \\
\pm 0,03\end{array}$ & 0,008 & 0,012 & $\begin{array}{l}0,77 \\
\pm 0,05\end{array}$ & $\begin{array}{l}1,28 \\
\pm 0,13 \\
\end{array}$ & $<0,001$ & $<0,001$ & $<0,001$ \\
\hline 10. Тривога психічна & $\begin{array}{c}0,34 \\
\pm 0,03 \\
\end{array}$ & $\begin{array}{l}0,48 \\
\pm 0,05 \\
\end{array}$ & $\begin{array}{c}0,56 \\
\pm 0,04 \\
\end{array}$ & 0,005 & 0,116 & $\begin{array}{c}1,21 \\
\pm 0,06 \\
\end{array}$ & $\begin{array}{r}1,54 \\
\pm 0,12 \\
\end{array}$ & 0,009 & $<0,001$ & $<0,001$ \\
\hline 11 Тривога соматична & $\begin{array}{c}0,27 \\
\pm 0,02 \\
\end{array}$ & $\begin{array}{l}0,38 \\
\pm 0,04 \\
\end{array}$ & $\begin{array}{l}0,55 \\
\pm 0,05 \\
\end{array}$ & 0,009 & 0,002 & $\begin{array}{l}1,28 \\
\pm 0,05 \\
\end{array}$ & $\begin{array}{l}1,58 \\
\pm 0,09 \\
\end{array}$ & 0,003 & $<0,001$ & $<0,001$ \\
\hline $\begin{array}{l}12 \text { ШКТ-соматичні порушення } \\
\text { (симптоми) }\end{array}$ & $\begin{array}{l}0,09 \\
\pm 0,01 \\
\end{array}$ & $\begin{array}{c}0,16 \\
\pm 0,02 \\
\end{array}$ & $\begin{array}{c}0,22 \\
\pm 0,03 \\
\end{array}$ & 0,010 & 0,060 & $\begin{array}{c}0,48 \\
\pm 0,03 \\
\end{array}$ & $\begin{array}{c}0,64 \\
\pm 0,07 \\
\end{array}$ & 0,020 & $<0,001$ & $<0,001$ \\
\hline $\begin{array}{l}\text { 13. Загальносоматичні } \\
\text { симптоми }\end{array}$ & $\begin{array}{c}0,24 \\
\pm 0,02 \\
\end{array}$ & $\begin{array}{c}0,34 \\
\pm 0,03\end{array}$ & $\begin{array}{l}0,46 \\
\pm 0,03\end{array}$ & 0,001 & 0,006 & $\begin{array}{c}0,81 \\
\pm 0,04\end{array}$ & $\begin{array}{l}0,83 \\
\pm 0,07\end{array}$ & 0,431 & $<0,001$ & $<0,001$ \\
\hline 14. Розлади сексуальної сфери & $\begin{array}{l}0,10 \\
\pm 0,01 \\
\end{array}$ & $\begin{array}{c}0,18 \\
\pm 0,03 \\
\end{array}$ & $\begin{array}{c}0,25 \\
\pm 0,03 \\
\end{array}$ & 0,009 & 0,058 & $\begin{array}{c}0,87 \\
\pm 0,05 \\
\end{array}$ & $\begin{array}{c}0,87 \\
\pm 0,10 \\
\end{array}$ & 0,499 & $<0,001$ & $<0,001$ \\
\hline 15. Іпохондрія & $\begin{array}{c}0,10 \\
\pm 0,02 \\
\end{array}$ & $\begin{array}{c}0,16 \\
\pm 0,03 \\
\end{array}$ & $\begin{array}{c}0,15 \\
\pm 0,04 \\
\end{array}$ & 0,057 & 0,417 & $\begin{array}{c}0,51 \\
\pm 0,05 \\
\end{array}$ & $\begin{array}{c}0,74 \\
\pm 0,15 \\
\end{array}$ & 0,075 & $<0,001$ & $<0,001$ \\
\hline $\begin{array}{l}\text { 16. Зменшення маси тіла } \\
\text { (за анамнестичними даними) }\end{array}$ & $\begin{array}{l}0,09 \\
\pm 0,01 \\
\end{array}$ & $\begin{array}{l}0,18 \\
\pm 0,04 \\
\end{array}$ & $\begin{array}{l}0,22 \\
\pm 0,03 \\
\end{array}$ & 0,010 & 0,171 & $\begin{array}{l}0,55 \\
\pm 0,05 \\
\end{array}$ & $\begin{array}{l}0,68 \\
\pm 0,11 \\
\end{array}$ & 0,124 & $<0,001$ & $<0,001$ \\
\hline $\begin{array}{l}\text { 17. Ставлення до свого захво- } \\
\text { рювання }\end{array}$ & $\begin{array}{c}0,83 \\
\pm 0,04 \\
\end{array}$ & $\begin{array}{l}0,75 \\
\pm 0,06 \\
\end{array}$ & $\begin{array}{c}1,24 \\
\pm 0,06 \\
\end{array}$ & 0,143 & $<0,001$ & $\begin{array}{l}1,13 \\
\pm 0,05 \\
\end{array}$ & $\begin{array}{c}0,71 \\
\pm 0,09 \\
\end{array}$ & $<0,001$ & 0,342 & $<0,001$ \\
\hline HDRS сума & $\begin{array}{c}4,33 \\
\pm 0,22\end{array}$ & $\begin{array}{l}5,98 \\
\pm 0,42\end{array}$ & $\begin{array}{l}8,03 \\
\pm 0,40\end{array}$ & $<0,001$ & $<0,001$ & $\begin{array}{l}16,43 \\
\pm 0,39\end{array}$ & $\begin{array}{l}18,88 \\
\pm 1,18\end{array}$ & 0,025 & $<0,001$ & $<0,001$ \\
\hline
\end{tabular}

Примітки. Середні значення показників подано у форматі «середня арифметична \pm стандартна похибка середньої арифметичної» $(M \pm m) ; p$ - відмінності середніх значень в групах порівняння (достовірні відмінності $(p<0,05)$ виділені заливкою сірого кольору)

Отже, отримані результати підтверджують сучасні уявлення про те, що саме жінки $\epsilon$ найбільш вразливим контингентом щодо несприятливого впливу ПВО на стан їхнього психічного здоров'я [9-11].

Сучасне персоніфіковане лікування потребує вибору оптимальних мішеней для терапевтичних втручань. Тому останній етап цієї роботи був при- свячений визначенню стійких сполучень проявів депресії (типових симптомокомплексів, доступних для спостереження під час використання шкали HDRS) у респондентів-жінок, що мали ПВО (включно родичок хворих на А3). Це завдання вирішували застосуванням кластерного аналізу, результати якого подано на рис. 4. 

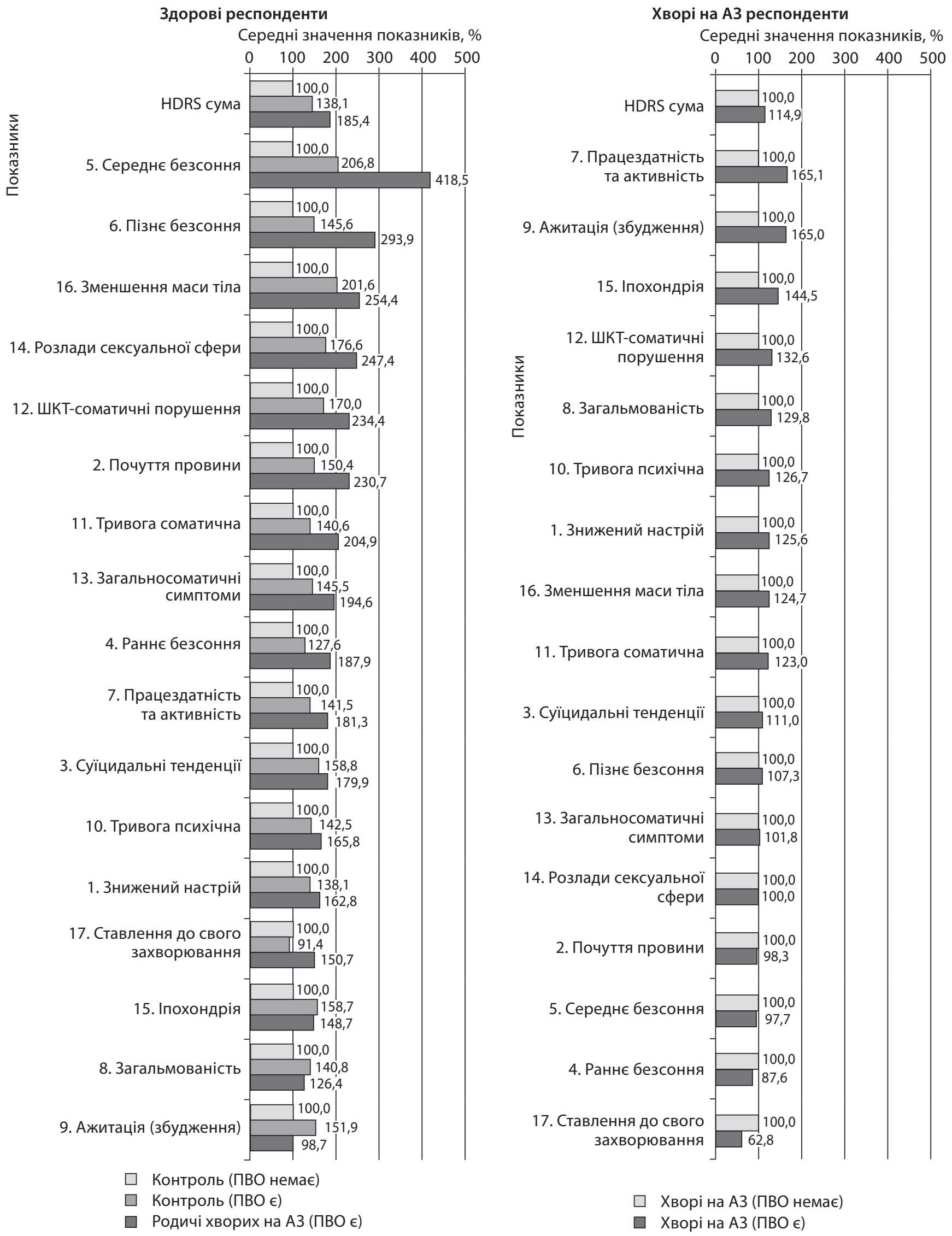

За 100 \% прийнято середні значення показників шкали HDRS у респондентів контрольної групи без ПВО

Puc. 2. Вплив наявності ПВО на показники афективного статусу хворих на АЗ і здорових респондентів за результатами обстеження з використанням шкали HDRS. Показники наведені в порядку зменшення згаданого впливу в групі родичів хворих на АЗ (для здорових респондентів) і в групі хворих з ПВО (для хворих на АЗ респондентів) 
Таблиця 4. Середні значення показників за шкалою HDRS у здорових респондентів з урахуванням їхньої статі залежно від наявності/відсутності питущих в оточенні

\begin{tabular}{|c|c|c|c|c|c|c|c|c|c|c|c|c|}
\hline \multirow{3}{*}{$\begin{array}{c}\text { Показники } \\
\text { (прояви депресії) }\end{array}$} & \multicolumn{3}{|c|}{ Чоловіки, $n=391$} & \multicolumn{2}{|c|}{$p$} & \multicolumn{3}{|c|}{ Жінки, $n=811$} & \multicolumn{4}{|c|}{$p$} \\
\hline & \multicolumn{2}{|c|}{$\begin{array}{l}\text { Контроль («К»), } \\
\quad n=310\end{array}$} & \multirow{2}{*}{ 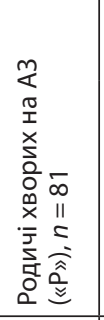 } & \multirow[b]{2}{*}{ 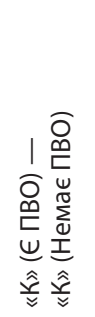 } & \multirow[b]{2}{*}{ 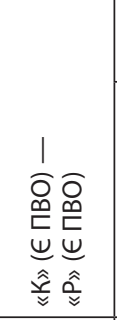 } & \multicolumn{2}{|c|}{$\begin{array}{c}\text { Контроль, } \\
n=654\end{array}$} & \multirow{2}{*}{ 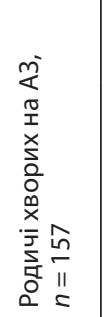 } & \multirow[b]{2}{*}{ 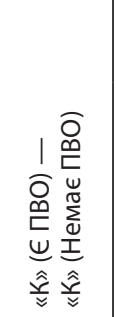 } & \multirow[b]{2}{*}{ 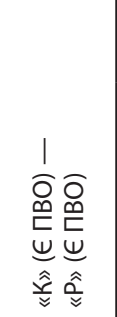 } & \multirow{2}{*}{ 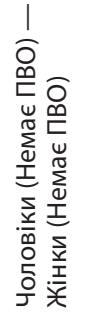 } & \multirow{2}{*}{ 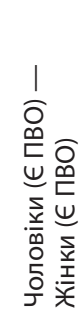 } \\
\hline & 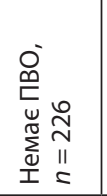 & 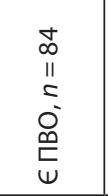 & & & & 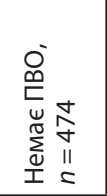 & 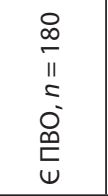 & & & & & \\
\hline 1. Знижений настрій & $\begin{array}{c}0,44 \\
\pm 0,06\end{array}$ & $\begin{array}{c}0,51 \\
\pm 0,10\end{array}$ & $\begin{array}{c}0,46 \\
\pm 0,07\end{array}$ & 0,293 & 0,364 & $\begin{array}{c}0,52 \\
\pm 0,04\end{array}$ & $\begin{array}{c}0,76 \\
\pm 0,07\end{array}$ & $\begin{array}{c}0,97 \\
\pm 0,08\end{array}$ & 0,003 & 0,027 & 0,158 & 0,023 \\
\hline 2. Почуття провини & $\begin{array}{c}0,21 \\
\pm 0,04\end{array}$ & $\begin{array}{c}0,33 \\
\pm 0,08\end{array}$ & $\begin{array}{c}0,36 \\
\pm 0,08\end{array}$ & 0,086 & 0,383 & $\begin{array}{c}0,24 \\
\pm 0,03\end{array}$ & $\begin{array}{c}0,35 \\
\pm 0,05\end{array}$ & $\begin{array}{c}0,61 \\
\pm 0,06\end{array}$ & 0,029 & 0,001 & 0,302 & 0,408 \\
\hline 3. Суїцидальні тенденції & $\begin{array}{c}0,17 \\
\pm 0,04\end{array}$ & $\begin{array}{c}0,16 \\
\pm 0,06\end{array}$ & $\begin{array}{c}0,08 \\
\pm 0,03\end{array}$ & 0,477 & 0,102 & $\begin{array}{c}0,10 \\
\pm 0,02\end{array}$ & $\begin{array}{c}0,21 \\
\pm 0,05\end{array}$ & $\begin{array}{c}0,29 \\
\pm 0,05\end{array}$ & 0,024 & 0,115 & 0,074 & 0,300 \\
\hline $\begin{array}{l}\text { 4. Раннє безсоння (труд- } \\
\text { нощі при засинанні) }\end{array}$ & $\begin{array}{c}0,33 \\
\pm 0,04\end{array}$ & $\begin{array}{c}0,29 \\
\pm 0,06\end{array}$ & $\begin{array}{c}0,45 \\
\pm 0,08\end{array}$ & 0,287 & 0,054 & $\begin{array}{c}0,28 \\
\pm 0,02\end{array}$ & $\begin{array}{c}0,41 \\
\pm 0,05\end{array}$ & $\begin{array}{c}0,61 \\
\pm 0,05\end{array}$ & 0,005 & 0,004 & 0,111 & 0,060 \\
\hline 5. Середнє безсоння & $\begin{array}{c}0,11 \\
\pm 0,03\end{array}$ & $\begin{array}{c}0,15 \\
\pm 0,05\end{array}$ & $\begin{array}{c}0,33 \\
\pm 0,06\end{array}$ & 0,224 & 0,016 & $\begin{array}{c}0,14 \\
\pm 0,02\end{array}$ & $\begin{array}{c}0,32 \\
\pm 0,04\end{array}$ & $\begin{array}{c}0,64 \\
\pm 0,05\end{array}$ & $<0,001$ & $<0,001$ & 0,183 & 0,008 \\
\hline $\begin{array}{l}\text { 6. Пізнє безсоння (ранні } \\
\text { пробудження) }\end{array}$ & $\begin{array}{c}0,21 \\
\pm 0,04\end{array}$ & $\begin{array}{c}0,28 \\
\pm 0,07\end{array}$ & $\begin{array}{c}0,50 \\
\pm 0,08\end{array}$ & 0,191 & 0,018 & $\begin{array}{c}0,23 \\
\pm 0,02\end{array}$ & $\begin{array}{c}0,34 \\
\pm 0,05\end{array}$ & $\begin{array}{c}0,73 \\
\pm 0,06\end{array}$ & 0,015 & $<0,001$ & 0,354 & 0,210 \\
\hline $\begin{array}{l}\text { 7. Працездатність та ак- } \\
\text { тивність }\end{array}$ & $\begin{array}{c}0,31 \\
\pm 0,05\end{array}$ & $\begin{array}{c}0,41 \\
\pm 0,09\end{array}$ & $\begin{array}{c}0,49 \\
\pm 0,07\end{array}$ & 0,189 & 0,241 & $\begin{array}{c}0,37 \\
\pm 0,03\end{array}$ & $\begin{array}{c}0,53 \\
\pm 0,06\end{array}$ & $\begin{array}{c}0,71 \\
\pm 0,06\end{array}$ & 0,006 & 0,017 & 0,185 & 0,118 \\
\hline 8. Загальмованість & $\begin{array}{c}0,13 \\
\pm 0,03\end{array}$ & $\begin{array}{c}0,18 \\
\pm 0,05\end{array}$ & $\begin{array}{c}0,11 \\
\pm 0,04\end{array}$ & 0,203 & 0,166 & $\begin{array}{c}0,12 \\
\pm 0,02\end{array}$ & $\begin{array}{c}0,17 \\
\pm 0,04\end{array}$ & $\begin{array}{c}0,18 \\
\pm 0,03\end{array}$ & 0,114 & 0,452 & 0,445 & 0,470 \\
\hline 9. Ажитація (збудження) & $\begin{array}{c}0,21 \\
\pm 0,04\end{array}$ & $\begin{array}{c}0,24 \\
\pm 0,07\end{array}$ & $\begin{array}{c}0,24 \\
\pm 0,06\end{array}$ & 0,363 & 0,487 & $\begin{array}{c}0,25 \\
\pm 0,03\end{array}$ & $\begin{array}{c}0,42 \\
\pm 0,06\end{array}$ & $\begin{array}{c}0,24 \\
\pm 0,04\end{array}$ & 0,005 & 0,004 & 0,208 & 0,026 \\
\hline 10. Тривога психічна & $\begin{array}{c}0,24 \\
\pm 0,04\end{array}$ & $\begin{array}{c}0,37 \\
\pm 0,08\end{array}$ & $\begin{array}{c}0,40 \\
\pm 0,08\end{array}$ & 0,090 & 0,384 & $\begin{array}{c}0,38 \\
\pm 0,03\end{array}$ & $\begin{array}{c}0,53 \\
\pm 0,06\end{array}$ & $\begin{array}{c}0,64 \\
\pm 0,05\end{array}$ & 0,015 & 0,089 & 0,006 & 0,049 \\
\hline 11 Тривога соматична & $\begin{array}{c}0,21 \\
\pm 0,04\end{array}$ & $\begin{array}{c}0,33 \\
\pm 0,07\end{array}$ & $\begin{array}{c}0,36 \\
\pm 0,06\end{array}$ & 0,069 & 0,360 & $\begin{array}{c}0,30 \\
\pm 0,03\end{array}$ & $\begin{array}{c}0,40 \\
\pm 0,05\end{array}$ & $\begin{array}{c}0,65 \\
\pm 0,06\end{array}$ & 0,032 & 0,001 & 0,037 & 0,193 \\
\hline $\begin{array}{l}12 \text { ШКТ-соматичні пору- } \\
\text { шення (симптоми) }\end{array}$ & $\begin{array}{c}0,09 \\
\pm 0,02\end{array}$ & $\begin{array}{c}0,19 \\
\pm 0,05\end{array}$ & $\begin{array}{c}0,11 \\
\pm 0,04\end{array}$ & 0,037 & 0,108 & $\begin{array}{c}0,09 \\
\pm 0,01\end{array}$ & $\begin{array}{c}0,14 \\
\pm 0,03\end{array}$ & $\begin{array}{c}0,27 \\
\pm 0,04\end{array}$ & 0,061 & 0,003 & 0,418 & 0,214 \\
\hline $\begin{array}{l}\text { 13. Загальносоматичні } \\
\text { симптоми }\end{array}$ & $\begin{array}{c}0,20 \\
\pm 0,03\end{array}$ & $\begin{array}{c}0,23 \\
\pm 0,05\end{array}$ & $\begin{array}{c}0,31 \\
\pm 0,05\end{array}$ & 0,329 & 0,123 & $\begin{array}{c}0,25 \\
\pm 0,02\end{array}$ & $\begin{array}{c}0,40 \\
\pm 0,04\end{array}$ & $\begin{array}{c}0,54 \\
\pm 0,04\end{array}$ & 0,001 & 0,007 & 0,080 & 0,004 \\
\hline $\begin{array}{l}\text { 14. Розлади сексуальної } \\
\text { сфери }\end{array}$ & $\begin{array}{c}0,15 \\
\pm 0,03\end{array}$ & $\begin{array}{c}0,15 \\
\pm 0,05\end{array}$ & $\begin{array}{c}0,24 \\
\pm 0,06\end{array}$ & 0,456 & 0,126 & $\begin{array}{c}0,08 \\
\pm 0,02\end{array}$ & $\begin{array}{c}0,19 \\
\pm 0,04\end{array}$ & $\begin{array}{c}0,25 \\
\pm 0,04\end{array}$ & 0,003 & 0,126 & 0,031 & 0,266 \\
\hline 15. Іпохондрія & $\begin{array}{c}0,11 \\
\pm 0,03\end{array}$ & $\begin{array}{c}0,19 \\
\pm 0,07\end{array}$ & $\begin{array}{c}0,16 \\
\pm 0,06\end{array}$ & 0,145 & 0,384 & $\begin{array}{c}0,10 \\
\pm 0,02\end{array}$ & $\begin{array}{c}0,15 \\
\pm 0,04\end{array}$ & $\begin{array}{c}0,15 \\
\pm 0,04\end{array}$ & 0,120 & 0,480 & 0,411 & 0,305 \\
\hline $\begin{array}{l}\text { 16. Зменшення маси тіла } \\
\text { (за анамнестичними да- } \\
\text { ними) }\end{array}$ & $\begin{array}{c}0,11 \\
\pm 0,03\end{array}$ & $\begin{array}{c}0,22 \\
\pm 0,07\end{array}$ & $\begin{array}{c}0,10 \\
\pm 0,04\end{array}$ & 0,060 & 0,065 & $\begin{array}{c}0,08 \\
\pm 0,02\end{array}$ & $\begin{array}{c}0,15 \\
\pm 0,04\end{array}$ & $\begin{array}{c}0,28 \\
\pm 0,05\end{array}$ & 0,042 & 0,017 & 0,185 & 0,190 \\
\hline $\begin{array}{l}\text { 17. Ставлення до свого } \\
\text { захворювання }\end{array}$ & $\begin{array}{c}0,77 \\
\pm 0,06\end{array}$ & $\begin{array}{c}0,66 \\
\pm 0,10\end{array}$ & $\begin{array}{c}1,56 \\
\pm 0,08\end{array}$ & 0,166 & $<0,001$ & $\begin{array}{c}0,85 \\
\pm 0,04\end{array}$ & $\begin{array}{c}0,80 \\
\pm 0,07\end{array}$ & $\begin{array}{c}1,08 \\
\pm 0,07\end{array}$ & 0,258 & 0,002 & 0,161 & 0,125 \\
\hline HDRS сума & $\begin{array}{c}4,09 \\
\pm 0,41\end{array}$ & $\begin{array}{c}4,96 \\
\pm 0,75\end{array}$ & $\begin{array}{c}6,29 \\
\pm 0,60\end{array}$ & 0,153 & 0,084 & $\begin{array}{c}4,44 \\
\pm 0,25\end{array}$ & $\begin{array}{c}6,44 \\
\pm 0,51\end{array}$ & $\begin{array}{c}8,91 \\
\pm 0,51\end{array}$ & $<0,001$ & $<0,001$ & 0,230 & 0,051 \\
\hline
\end{tabular}


Жінки

Середні значення показників, \% $\begin{array}{llllll}0 & 100 & 200 & 300 & 400 & 500\end{array}$

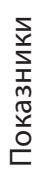

5. Середнє безсоння

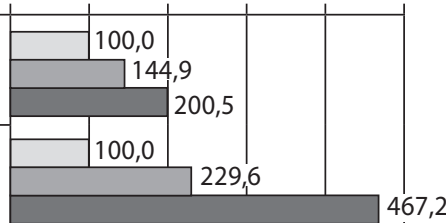

16. Зменшення маси тіла

14. Розлади сексуальної сфери

6. Пізнє безсоння

3. Суїцидальні тенденції

12. ШКТ-соматичні порушення

2. Почуття провини

4. Раннє безсоння

11. Тривога соматична

3. Загальносоматичні симптоми

7. Працездатність та активність

1. Знижений настрій

10. Тривога психічна

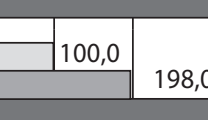

\section{8,0}
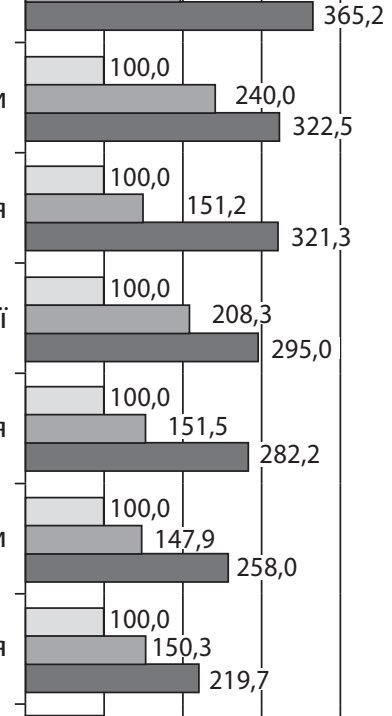

$$
\begin{array}{|l|l|}
\hline & 100,0 \\
\hline & 135,0 \\
\hline & 218,0 \\
\hline & \\
\hline & 100,0
\end{array}
$$

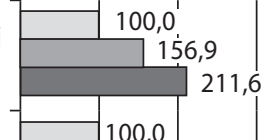

每

146,2

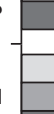

100,0

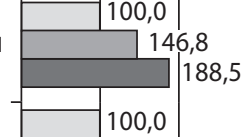

88,5

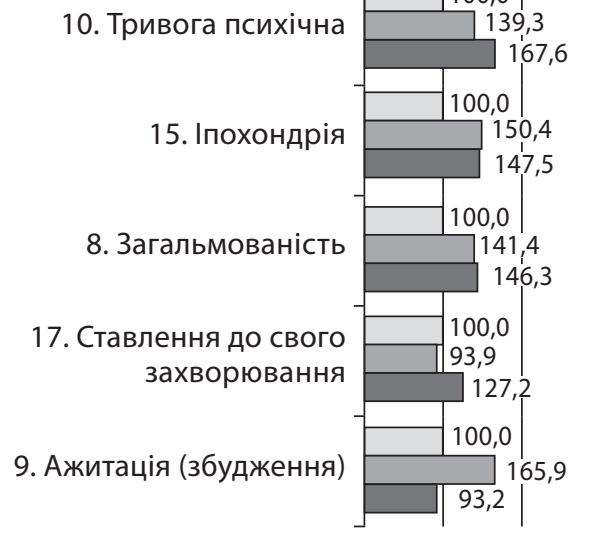

$\square$ Контроль (ПВО немає)

$\square$ Контроль (ПВО $\epsilon$ )

$\square$ Родичі хворих на АЗ (ПВО $\epsilon$ )
Чоловіки

Середні значення показників, \%

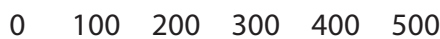

HDRS сума

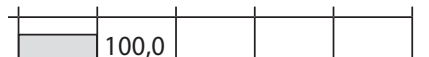

5. Середнє безсоння

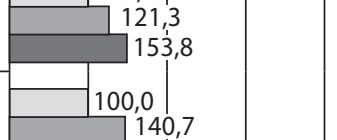

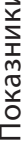

17. Ставлення до свого захворювання

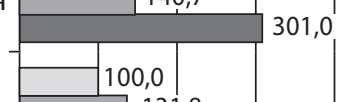

6. Пізнє безсоння

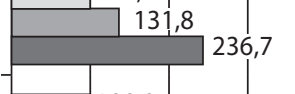

Почуття провини

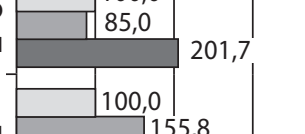

11. Тривога соматична

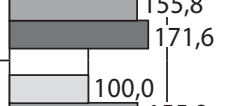

$$
\text { . }
$$

14. Розлади сексуальної сфери

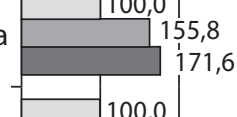

10. Тривога психічна
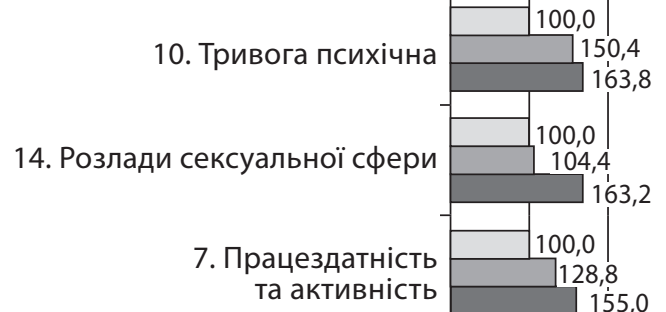

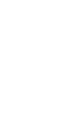

12. ШКТ-соматичні порушення

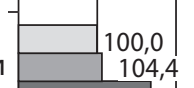
\begin{tabular}{r|r|} 
& 100,0 \\
7. Працездатність & 128,8 \\
та активність & 153,2
\end{tabular}

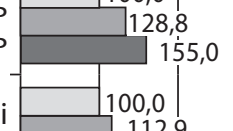

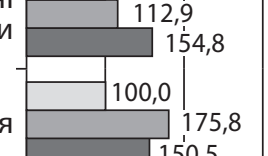

9. Ажитація (збудження)

15. Іпохондрія

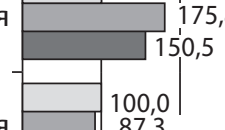

4. Раннє безсоння
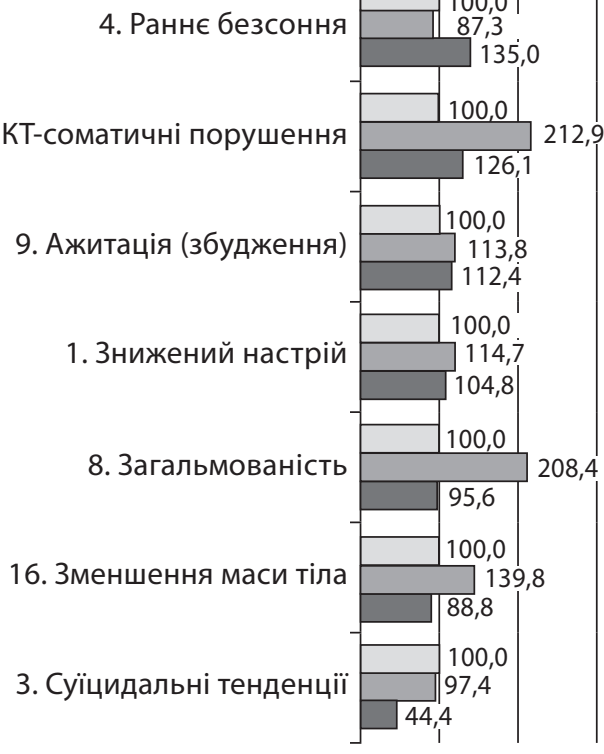

$$
\begin{array}{ll}
\square & \text { Контроль (ПВО немає) } \\
\square \quad \text { Контроль (ПВО } \epsilon) \\
\square \quad \text { Родичі хворих на АЗ (ПВО } \epsilon)
\end{array}
$$

Puc. 3. Вплив наявності питущих в оточенні на показники афективного статусу здорових респондентів різної статі за результатами обстеження з використанням шкали HDRS. Показники наведені в порядку зменшення згаданого впливу в групах родичів хворих на алкогольну залежність відповідної статі 


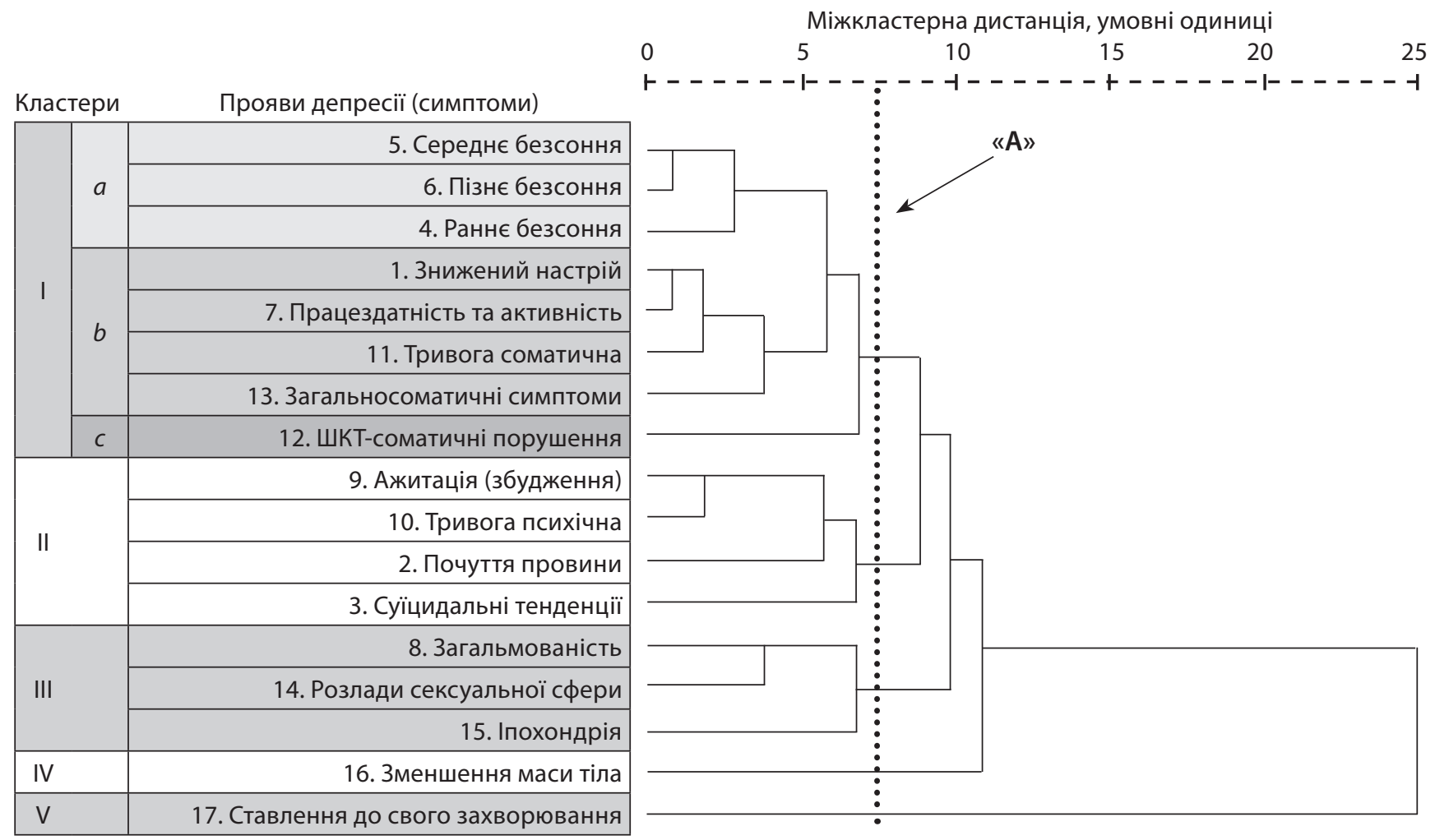

PUс. 4. Кластерна структура проявів депресії, які оцінено за допомогою шкали HDRS, у респондентів-жінок, що мають питущих в оточенні (включно родичок хворих на АЗ)

Примітки: Ієрархічний кластерний аналіз виконано за допомогою програмного пакету SPSS-15 з такими налаштуваннями: метод кластеризації — міжгруповий зв'язок; інтервал — кореляція Пірсона. Літерою «А» позначена пунктирна лінія, яка відповідає міжкластерній дистанції (7 умовних одиниць), обраної для формування кластерів

Зрозуміло, що кількість кластерів в процесі такого аналізу буде залежати від розмірів міжкластерної дистанції, обраної для їхнього (кластерів) визначення (чим менша дистанція, тим більше кластерів). За результатами аналізу отриманої дендрограми для формування кластерів було обрано міжкластерну дистанцію в 7 умовних одиниць. На думку авторів цієї статті, така міжкластерна дистанція $\epsilon$ розумним компромісом між потребами клінічної диференціації і кількістю кластерів (симптомокомплексів).

Як можна бачити, в результаті було отримано п'ять кластерів (позначених на рис. 4 римськими цифрами), три перших з них $\epsilon$ справжніми симптомокомплексами, а два останніх - окремими симптомами (проявами депресії).

Кластер I (інсомнічно-соматоформний) $\epsilon$ найбільшим за кількістю проявів депресії, що входять до нього. Він охоплює 8 із 17 симптомів, що оцінюють за шкалою HDRS. В його складі можна виокремити три субкластери, пов'язані між собою, а саме: субкластер Іа (інсомнічний), який поєднує у собі всі види безсоння (раннє, середн $\epsilon$ та пізн $\epsilon)$; субкластер Ib (астено-соматоформний), який представлений зниженням працездатності та активності, а також загальносоматичними симптомами і пов'язаною з ними соматичною тривогою на тлі зниженого настрою; і субкластер Іс, єдиним складником якого $\epsilon$ соматичні порушення з боку шлунково-кишкового тракту.
Кластер II (анксіозно-ажитаційний) має у своєму складі психічну тривогу, ажитацію i, що особливо небезпечно, почуття провини з суїцидальними тенденціями (останні спостерігались винятково у родичок хворих на А3, насамперед - їхніх матерів)

Кластер III (іпохондричний), окрім власне іпохондрії, мав у своєму складі розлади сексуальної сфери та загальмованість.

Кластери IV i V були представлені єдиними симптомами (зменшенням маси тіла і зниженням критичності у ставленні до свого захворювання). Ці симптоми були слабко пов'язаними із іншими проявами депресії і тому виявились рівновіддаленими від решти симптомокомплексів, утворивши окремі кластери. Водночас кластер $V$ виявився найвіддаленішим від решти кластерів у просторі ознак шкали HDRS. Це пов'язано із тим, що багато хто із обстежених жінок з ПВО не були хворими на ДР, і тому відповідний пункт шкали HDRS фактично був незастосовним до них.

Загальна кількість обстежених жінок, що мали ПВО (включно родичок хворих на АЗ), становила 331 особу, а кількість виявлених серед них респонденток з ознаками ДР (понад 7 балів за шкалою HDRS) становила 147 осіб (або 44,41 \% від загальної кількості жінок цієї категорії). Тому для підвищення надійності висновків про кластерну структуру проявів депресії і, навіть більше, висновків про поширення відповідних клінічних варіантів ДР внаслідок впливу ПВО потрібні подальші дослідження. 
Отже, результати проведеного дослідження дали змогу дійти таких висновків.

1. Вивчено вплив питущих на афективний статус представників їхнього мікросоціального оточення за допомогою опитувальника міжнародного дослідницького консорціуму GENAHTO.

2. Показано, що наявність будь-яких питущих в оточенні респондентів-жінок істотно підвищує відносну частку осіб з депресивними розладами всіх ступенів важкості (легкого - на 45,99 \%, середнього - на 45,57 \%, тяжкого і вкрай тяжкого на $154,68 \%$, при $p<0,05)$, тоді як у респондентів чоловічої статі така наявність практично не змінювала відносну частку осіб з депресивними розладами.

3. Доведено, що виразність окремих проявів депресивних розладів (симптомів) у жінок за наявності в оточенні питущого збільшується не рівною мірою, водночас найбільшими темпами наростають середнє і пізнє безсоння; зменшення маси тіла, розлади сексуальної сфери; суїцидальні тенденції та почуття провини (в 2,29; в 1,48; в 1,88; в 2,38; в 2, 10 і в 1,46 раза порівняно жінками без питущих в оточенні, при $p \leq 0,04)$.

4. За результатами кластерного аналізу даних, отриманих за допомогою шкали HDRS встановлено, що прояви депресивних розладів у різних респонденток з питущими в оточенні утворюють такі типові симптомокомплекси: інсомнічно-соматоформний, іпохондричний та анксіозно-ажитаційний (останній - 3 відчуттям власної провини і підвищеним ризиком суїцидальної активності).

5. Для визначення поширеності різних клінічних варіантів депресивних розладів (з описаними вище типовими симптомокомплексами), а також для розроблення диференційованої терапії для кожного із них потрібні подальші дослідження.

Далі буде.

\section{Список літератури}

1. Surveying the range and magnitude of alcohol's harm to others in Australia / Laslett A-M., Room R., Ferris J. [et al.] // Addiction. 2011, 106(9), 1603-11. DOI: 10.1111/j.13600443.2011.03445.x.

2. Connor J., Casswell S. Alcohol-related harm to others in New Zealand: evidence of the burden and gaps in knowledge // The New Zealand Medical Journal. 2012, 125(1360), 11-27. PMID: 22932651.

3. Dussaillant F., Fernandez M. Alcohol's harm to others' well-being and health: a comparison between Chile and Australia // Alcohol and Alcoholism. 2015, 50(3), 346-51. DOI: 10.1093/alcalc/agv002.

4. Temporal Patterns of Alcohol Consumption and AlcoholRelated Road Accidents in Young Swiss Men: Seasonal, Weekday and Public Holiday Effects / Foster S., Gmel G., Estévez N. [et al.] // Alcohol and Alcoholism. 2015, 50(5), 565-72. DOI: 10.1093/alcalc/agv037.

5. Ferris J., Killian J., Lloyd B. Alcohol-related serious road traffic injuries between 2000 and 2010: A new perspective to deal with administrative data in Australia // The International Journal of Drug Policy. 2017, 43, 104-112. DOI: 10.1016/j. drugpo.2017.02.015.
6. Alcohol and drugs use among drivers injured in road accidents in Campania (Italy): A 8-years retrospective analysis / Carfora A., Campobasso C. P., Cassandro P. [et al.] // Forensic Science International. 2018, 288, 291-296. DOI: 10.1016/j. forsciint.2018.05.003.

7. The Dynamics of Partner Violence and Alcohol Use in Couples: Research Methods. / Burge S.K., Katerndahl D. A., Becho J. [et al.] // Violence and Victims. 2019. 34(1), 136-156.

8. Gomez J., Orchowski L., Pearlman D. N. Alcohol Use and Intimate Partner Violence Among Community College Women: An Exploration of Protective Factors. Violence and Gender. 2019. 6(3), 187-195. DOI: 10.1089/vio.2018.0023.

9. The impacts of others' drinking on mental health / Ferris J. A., Laslett A.-M., Livingston M. [et al.] // Medical Journal of Australia. 2011. 195(3), S22-S26. DOI: 10.5694/j.13265377.2011.tb03261.x.

10. Karriker-Jaffe K. J., Li L., Greenfield T. K. Estimating mental health impacts of alcohol's harms from other drinkers: Using propensity scoring methods with national cross-sectional data from the United States // Addiction. 2018 Oct; 113(10): 1826-1839. DOI: 10.1111/add.14283.

11. The effects of alcohol-related harms to others on self-perceived mental well-being in a Canadian sample / LewisLaietmark C., Wettlaufer A., Shield K. D. [et al.] // International Journal of Public Health. 2017. 62(6),669-678. DOI: 10.1007/ s00038-016-0924-7.

12. Drug harms in the UK: a multicriteria decision analysis / Nutt D. J., King L. A., Phillips L. D. // Lancet. 2010. 376(9752), 1558-1565. DOI: https://doi.org/10.1016/S01406736(10)61462-6.

13. WHO, 2010. Global strategy to reduce the harmful use of alcohol 2010. URI: https://www.who.int/publications/i/ item/9789241599931.

14. Wilsnack, S. C., Greenfield T. K., Bloomfield K. The GENAHTO Project (Gender and Alcohol's Harm to Others): Design and methods for a multinational study of alcohol's harm to persons other than the drinker // The International Journal of Alcohol and Drug Research. 2018; 7(2), 37-47. DOI: 10.7895/ijadr.253.

15. Питущі особи в мікросоціальному оточенні мешканців України. Вікові та ґендерні особливості / Лінський І.В. Кузьмінов В. Н., Мінко О. І. [та ін.] // Український вісник психоневрології. 2021. Т. 29, вип. 1 (106). С. 4-11. DOI: https://doi.org/10.36927/2079-0325-V29-is1-2021-1.

16. Прояви несприятливого впливу питущих на дорослих В мікросоціальному оточенні / Лінський І.В. Кузьмінов В. Н., Мінко О. І. [та ін.] // Там само. 2021. Т. 29, вип. 2(107). С. 5-13. DOI: https://doi.org/10.36927/2079-0325-V29-is2-2021-1.

17. Особливості несприятливого впливу питущих на дітей в мікросоціальному оточенні / Лінський І.В. Кузьмінов В. Н., Мінко О. І. [та ін.] // Там само. 2021. Т. 29, вип. 3 (108). С. 5-11. DOI: https://doi.org/10.36927/20790325-V29-is3-2021-1.

18. Hamilton M. A rating scale for depression // The Journal of Neurology, Neurosurgery \& Psychiatry. 1960. 23, 56-61. DOI: https://doi.org/10.1136/jnnp.23.1.56.

19. Гублер Е. В. Вычислительные методы анализа и распознавания патологических процессов. Москва : Медицина, 1978. 294 с.

20. Лапач С. Н. Статистические методы в медико- биологических исследованиях с использованием Excel / С. Н. Лапач, А. В. Чубенко, П. Н. Бабич. Киев : «Моріон». 2000. 320 с.

21. Hill A.B. The Environment and Disease: Association or Causation? Proceedings of the Royal Society of Medicine. 1965. 58 (5): 295-300. PMID: 14283879.

Надійшла до редакиії 3.11 .2021 


\section{Відомості про авторів:}

ЛІНСЬКИЙ Ігор Володимирович, доктор медичних наук, професор, директор Державної установи «Інститут неврології, психіатрії та наркології Національної академії медичних наук України» (ДУ «ІНПН НАМН України»), професор кафедри неврології, психіатрії, наркології та медичної психології Харківського національного університету (ХНУ) імені В. Н. Каразіна, м. Харків, Україна; e-mail: i_linskiy@yahoo.com

КУЗьМІнОВ Валерій Никифорович, кандидат медичних наук, провідний науковий співробітник відділу невідкладної психіатрії та наркології ДУ «ІНПН НАМН України», м. Харків, Україна

МІНКО Олександр Іванович, доктор медичних наук, професор, завідувач відділу клінічної та соціальної наркології ДУ «ІНПН НАМН України», професор кафедри неврології, психіатрії, наркології та медичної психології ХНУ ім. В. Н. Каразіна, м. Харків, Україна

КОЖИНА Ганна Михайлівна, доктор медичних наук, професор, завідувач кафедри психіатрії, наркології, медичної психології та соціальної роботи Харківського національного медичного університету МОЗ України, м. Харків, Україна

ГРИНЕВИЧ Євгенія Геннадіївна, доктор медичних наук, професор, професор кафедри загальної, дитячої, судової психіатрії і наркології Національного університету охорони здоров'я України імені П. Л. Шупика, м. Київ, Україна

ОВЧАРЕНКО Микола Олексійович, доктор медичних наук, професор, завідувач кафедри неврології, психіатрії та наркології Луганського державного медичного університету МО3 України, м. Рубіжне, Україна

чУГУНОВ Вадим Віталійович, доктор медичних наук, професор, завідувач кафедри психіатрії, психотерапії, загальної та медичної психології, наркології та сексології Запорізького державного медичного університету (ЗДМУ) МОЗ України, м. Запоріжжя, Україна

ПОСТРЕЛКО Валентин Михайлович, доктор медичних наук, професор, завідувач кафедри внутрішньої медицини з курсом ендокринології Міжнародної академії екології та медицини, м. Київ, Україна

ДЕНИСЕНКО Михайло Михайлович доктор медичних наук, провідний науковий співробітник відділу невідкладної психіатрії та наркології ДУ «ІНПН НАМН України», м. Харків, Україна

плєХОВ Владислав Андрійович, аспірант кафедри психіатрії, психотерапії, загальної та медичної психології, наркології та сексології ЗДМУ МОЗ України, м. Запоріжжя, Україна

ТКАЧЕНКО Тетяна Володимирівна, кандидат психологічних наук, провідний науковий співробітник відділу невідкладної психіатрії та наркології ДУ «ІНПН НАМН України», м. Харків, Україна

ЗАДОРОЖНИЙ Володимир Володимирович, кандидат медичних наук, провідний науковий співробітник відділу невідкладної психіатрії та наркології ДУ «ІНПН НАМН України», м. Харків, Україна

МАЛИХІНА Наталія Анатоліївна,

МІНКО Олексій Олександрович,

ЛАКИНСЬКИЙ Роман Вікторович,

ВАСИЛЬЄВА Ольга Олександрівна,

ЮРЧЕНКО Ольга Миколаївна - кандидати медичних наук, старші наукові співробітники відділу невідкладної психіатрії та наркології ДУ «ІНПН НАМН України», м. Харків, Україна

ГЕРАСИМОВ Богдан Олексійович, молодший науковий співробітник відділу невідкладної психіатрії та наркології ДУ «ІНПН НАМН України», м. Харків, Україна

ГЕРАСИМОВ Дмитро Олексійович, молодший науковий співробітник відділу невідкладної психіатрії та наркології ДУ «ІНПН НАМН України», м. Харків, Україна
Information about the authors:

LINSKIY Igor, Doctor of Medical Sciences, Professor, Director of State Institution "Institute of Neurology, Psychiatry and Narcology of the National Academy of Medical Sciences of Ukraine" ("INPN of the NAMS of Ukraine" SI), Professor of the Department of Neurology, Psychiatry, Narcology and Medical Psychology of V. N. Karazin's Kharkiv National University, Kharkiv, Ukraine; e-mail: i_linskiy@yahoo.com

KUZMINOV Valerii, MD, PhD, Leading Researcher of the Department of Emergency Psychiatry and Narcology of "INPN of the NAMS of Ukraine" SI, Kharkiv, Ukraine

MINKO Oleksandr, Doctor of Medical Sciences, Professor, Head of the Department of Clinical and Social Narcology of "INPN of the NAMS of Ukraine" SI, Professor of the Department of Neurology, Psychiatry, Narcology and Medical Psychology of V. N. Karazin's Kharkiv National University, Kharkiv, Ukraine

KOZHYNA Ganna, Doctor of Medical Sciences, Professor, Head of the Department of Psychiatry, Narcology, Medical Psychology and Social Work of Kharkiv National Medical University of the Ministry of Health of Ukraine, Kharkiv, Ukraine

GRYNEVYCH Yevheniia, Doctor of Medical Sciences, Professor, Professor of the Department of General, Child, Forensic Psychiatry and Narcology of the Shupyk's National Healthcare University of Ukraine, Kyiv, Ukraine

OVCHARENKO Mykola, Doctor of Medical Sciences, Professor, Head of the Department of Neurology, Psychiatry and Narcology of Luhansk State Medical University of the Ministry of Health of Ukraine, Rubizhne, Ukraine

CHUGUNOV Vadym, Doctor of Medical Sciences, Professor, Head of the Department of Psychiatry, Psychotherapy, General and Medical Psychology, Narcology and Sexology of Zaporizhzhia State Medical University of the Ministry of Health of Ukraine, Zaporizhzhia, Ukraine

POSTRELKO Valentyn, Doctor of Medical Sciences, Professor, Head of the Department of Internal Medicine with a course in Endocrinology of International Academy of Ecology and Medicine, Kyiv, Ukraine

DENYSENKO Mykhailo Doctor of Medical Sciences, Leading Researcher of the Department of Emergency Psychiatry and Narcology of "INPN of the NAMS of Ukraine" SI, Kharkiv, Ukraine

PLEKHOV Vladyslav, graduate student of the Department of Psychiatry, Psychotherapy, General and Medical Psychology, Narcology and Sexology of Zaporizhzhia State Medical University of the Ministry of Health of Ukraine, Zaporizhzhia, Ukraine

TKACHENKO Tetiana, PhD of Psychological Sciences, Leading Researcher of the Department of Emergency Psychiatry and Narcology of "INPN of the NAMS of Ukraine" SI, Kharkiv, Ukraine

ZADOROZHNYI Volodymyr, MD, PhD, Leading Researcher of the Department of Emergency Psychiatry and Narcology of "INPN of the NAMS of Ukraine" SI, Kharkiv, Ukraine

MALYKHINA Natalia,

MINKO Oleksiy,

LAKINSKYI Roman,

VASILYEVA OIga,

YURCHENKO Olga - MD, PhD, Senior Researchers of the Department of Emergency Psychiatry and Narcology of "INPN of the NAMS of Ukraine" SI, Kharkiv, Ukraine

HERASYMOV Bohdan, Junior Researcher of the Department of Emergency Psychiatry and Narcology of "INPN of the NAMS of Ukraine" SI, Kharkiv, Ukraine.

HERASYMOV Dmytro, Junior Researcher of the Department of Emergency Psychiatry and Narcology of "INPN of the NAMS of Ukraine" Sl, Kharkiv, Ukraine 